\title{
Preliminary use of a fulvic acid, as a strategy to improve water use in saline soils
}

\section{Uso preliminar del ácido fúlvico, como estrategia para mejorar el uso del agua en suelos salinos}

Cristián Kremer, José Díaz, Oscar Seguel, Yasna Tapia

Originales: Recepción: 02/06/2020 - Aceptación: 22/03/2021

\begin{abstract}
An evaluation of a fulvic acid (FA) was made in a Loam soil, by selecting the best dose to achieve salt displacement under a drip emitter. In trial 1, PVC columns were filled with a loam soil and irrigated with a $\mathrm{KCl}$ solution of electrical conductivity (EC) of $12.5 \mathrm{dS} \mathrm{m}^{-1}$. Once the soil solution EC reached the value of the $\mathrm{KCl}$ solution, FA doses of 0, 2.1, 5.3 and $10.5 \mathrm{~kg} \mathrm{ha}^{-1}$ were applied. The bulk electric conductivity and soil chemical properties were evaluated after 6 irrigation cycles. In trial 2, the same soil salinized with the $\mathrm{KCl}$ solution was placed in $0.8 \mathrm{~m}^{3}$ containers. Two irrigations treatments were performed: a control and the best FA dose from trial 1. The displacement of the salt bulb created from irrigation with a dropper in the soil profile was characterized. In trial 1, the dose of $5.3 \mathrm{~kg} \mathrm{ha}^{-1}$ reached the lowest EC after the third irrigation. In trial 2, the selected dose reduced EC until $3.75 \mathrm{dS} \mathrm{m}^{-1}$ at $0.3 \mathrm{~m}$ depth at the third irrigation, saving.246 L of water compared to control. Additionally, the salinity bulbs were more horizontally extended in the FA treatment.
\end{abstract}

\section{Keywords}

soil conditioner $\bullet$ humic acid $\bullet$ soil electric conductivity $\bullet$ leaching fraction

Universidad de Chile. Facultad de Ciencias Agronómicas. Departamento de Ingeniería y Suelos. Avenida Santa Rosa 11315. La Pintana, Santiago. Chile.

* ckremer@uchile.cl 


\section{RESUMEN}

Se evaluó el uso del ácido fúlvico (FA) en un suelo franco, seleccionando la mejor dosis para lograr el desplazamiento de sal. En el ensayo 1, columnas de PVC se rellenaron con suelo franco y se regaron con una solución de $\mathrm{KCl}$ conductividad eléctrica (EC) $12,5 \mathrm{dS} \mathrm{m}^{-1}$. Cuando la EC de la solución suelo alcanzó el valor de la solución de $\mathrm{KCl}$, se aplicaron dosis de FA de $0 ; 2,1 ; 5,3$ y 10,5 $\mathrm{kg} \mathrm{ha}^{-1}$. Se evaluó la EC aparente y las propiedades químicas después de 6 ciclos de riego. En la prueba 2, el mismo suelo salinizado con la solución de $\mathrm{KCl}$ se colocó en recipientes de $0,8 \mathrm{~m}^{3}$. Se realizaron dos tratamientos de riego: control y la mejor dosis de FA obtenida del ensayo 1 . Se caracterizó el desplazamiento del bulbo salino creado a partir del riego por goteo en el perfil del suelo. En el ensayo 1, la dosis de 5,3 $\mathrm{kg} \mathrm{ha}^{-1}$ alcanzó la EC más baja después del tercer riego. En el ensayo 2, la dosis seleccionada redujo la EC hasta $3,75 \mathrm{dS} \mathrm{m}^{-1}$ a $0,3 \mathrm{~m}$ de profundidad en el tercer riego, ahorrando $246 \mathrm{~L}$ de agua. Además, los bulbos de salinidad se extendieron más horizontalmente en el tratamiento de FA.

\section{Palabras claves}

acondicionador de suelos • ácido húmico • conductividad eléctrica del suelo • fracción de lixiviación

\section{INTRODUCTION}

The management of saline soils for agricultural use is mostly based on the application of excessive volumes of irrigation water (above the water demand of the crop) so that salts are dissolved and leached out of the root zone. Such management is contradictory, precisely because water in arid and semi-arid regions, where soil salinization processes occur, is low in quantity as well as quality. Worldwide, over 50 million hectares of agricultural land have salinity problems, which, when added to the scarcity of water resources, forces us to seek new management perspectives for these soils. This is how different types of amendments and conditioners have been documented for the recovery of saline soils, such as gypsum, organic acids and different types of polyacrylamides, compost, etc., with positive results being reported $(3,10,12,20,24)$. Soil conditioners are naturally or chemically synthesized substances, which can improve soil quality and facilitate plant growth (1,2, 9). Accordingly, the incorporation of soil conditioners rich in organic matter (OM), of different types and origins, is becoming a common practice for soils affected by salts. The literature has reported different responses of saline soils to organic matter applications, which aimed to favor the movement of salts. These responses may be physical, such as the increase in coarse porosity and hydraulic conductivity $(5,15,18)$, chemical, due to interactions between the active part of certain functional groups, particularly carboxylic acids with salts (4) and biological, such as improvements in nutrient uptake $(\mathrm{N}, \mathrm{Ca}, \mathrm{P}, \mathrm{K}, \mathrm{Mg}, \mathrm{Fe}, \mathrm{Zn}$ and $\mathrm{Cu})(3,14,15)$. Thus, various mechanisms of OM reduce the negative effects of salinity, making it clear that it is a complex system, where different OM fractions can act in different ways, improving physical, chemical or biological conditions and promoting plant growth.

The agricultural supplies industry has recently put products on the market called "salt shifters", soil conditioners that combine soluble organic acids (humic and fulvic), polysaccharides and / or soluble polymers, which can adsorb cations and take them out of the root zone together with the irrigation water, leaching more salts with less water; however, they are poorly documented (24). On the other hand, the application of humic substances and their positive effect on the remediation of saline soils has been associated more with the indirect effect of fulvic acids, such as improving soil physical and chemical properties $(15,19)$, rather than their leaching effect. A chelating effect, in particular of fulvic acids, could mobilize the salts of the soil exchange complex and, with good irrigation management, produce effective leaching. In this regard, Osman and Ewees (2008) suggested that the charged functional groups of the organic acids (COO-) could retain and chelate cations, becoming them inactive or moving them deeper. 
Although there is a series of investigations related to the effects of the application of amendments on the chemical and physical properties of saline and sodic soils and their effect on crop production $(3,9,19)$, few studies have monitored the electrical conductivity in different soil layers after the application of amendments (26). Many of these studies have been conducted for the remediation of saline-sodic soils under field and laboratory conditions, but the spatial and temporal evaluation of the movement of solutes in the field is difficult, so the soil is generally evaluated in columns and under controllable conditions (13).

In this context, the aim of this study was to develop a preliminary evaluation to guide future research on soil salinity reclamation based on more efficient irrigation strategies with the use of fulvic acid (FA). The latter was accomplished through two trials; in the first one, it was tested three different doses of FA in a saline soil to select the best dose for salt leaching purposes. In the second trial it was used the dose selected previously to observe its effect on salt displacement in soil depth, with the use of drip irrigation.

\section{MATERIALS AND METHODS}

Two trials were carried out in a protected environment in the Irrigation and Soil Physics laboratories of the Faculty of Agronomy of the University of Chile, located in Santiago, Chile, coordinates $33^{\circ} 34^{\prime} 11^{\prime \prime} \mathrm{S}, 70^{\circ} 37^{\prime} 50^{\prime \prime} \mathrm{W}$.

\section{Treatments and experimental design}

Trial 1: A commercial conditioner derived from Leornardite was used, presented as soluble powder, pH 4.0 to 5.0 and a mass base composition of: FA $\left(700 \mathrm{~g} \mathrm{~kg}^{-1}\right)$, magnesium (5000 - $6000 \mathrm{mg} \mathrm{kg}^{-1}$ ), sulfur (5000 - $6000 \mathrm{mg} \mathrm{kg}^{-1}$ ), iron (4000 $\left.\mathrm{mg} \mathrm{kg}^{-1}\right)$, zinc (2.5 $\left.\mathrm{mg} \mathrm{kg}^{-1}\right)$, manganese (2500 mg kg-1) and copper (1000 mg kg-1), the manufacturer claims that the minerals are added to the final product as chelates. The experimental unit corresponded to a PVC column $0.2 \mathrm{~m}$ in diameter and $0.25 \mathrm{~m}$ in length with a fine net of $85 \mathrm{mesh}$ at its base to allow free drainage, filled with a loam soil. The soil was sieved at $4 \mathrm{~mm}$ and it was composed of $15 \%$ clay, $40 \%$ silt and $45 \%$ sand, particle density $2.53 \mathrm{Mg} \mathrm{m}^{-3}$ and $0.011 \mathrm{~g} \mathrm{~kg}^{-1}$ soil organic matter (SOM). Prior to salinization, the soil had an electrical conductivity measured in saturated paste (ECes) (22) of $1.63 \mathrm{dS} \mathrm{m}^{-1}$, a cation exchange capacity (CEC) of $19.8 \mathrm{cmol} \mathrm{kg}^{-1}$ (extraction in ammonium acetate) (22), and a pH of 8.16 (suspension and potentiometric determination) (22). The filling of the columns included a $5 \mathrm{~cm}$ layer of sand at the bottom, placing $15 \mathrm{~cm}$ of soil over this layer. The soil was settled through the application of successive loads of water, until reaching a bulk density of $1.4 \mathrm{Mg} \mathrm{m}^{-3}$. The column was salinized by the addition of potassium chloride $(\mathrm{KCl})$ in solution with an EC of $12.5 \mathrm{dS} \mathrm{m}^{-1}$. The experimental unit was irrigated several times with this solution until obtaining the same EC of the solution in the drainage water. No preferential flow was detected during the essay, so homogeneous condition of the soil was assumed. To verify the effectiveness of soil salinization without altering the samples, its porous electrical conductivity (ECp) was obtained based on its permittivity data measured by a FDR sensor (GS3, Decagon Devices, WA, USA) previously parameterized with the parameters from Hilhorst (2000). The results showed that the ECp was on average $12.1 \pm 0.94 \mathrm{dS} \mathrm{m}^{-1}(\mathrm{n}=12)$.

The experimental design was completely randomized, with three treatments plus one control, with three replicates each, totaling twelve soil columns. The treatments corresponded to FA based applications of 2.1 (T1), 5.3 (T2) and 10.5 (T3) kg ha-1 plus the control (T0) without application, which correspond to 6.6 (T1), 16.7 (T2) and 33 (T3) mg per column. The T1 dose was that recommended by the manufacturer $\left(2.1 \mathrm{~kg} \mathrm{ha}^{-1}\right)$ and the other two corresponded to progressive increases close to $100 \%$ of the previous treatment. It should be noted that the product is marketed as a stimulant for plant development, so there is no a specific recommended dose to promote the mobilization of salts.

Trial 2: The experimental unit was a container, with inner dimensions of $1.14 \mathrm{~m}$ length, $1.14 \mathrm{~m}$ width and $0.62 \mathrm{~m}$ height. This was filled with $50 \mathrm{~cm}$ of the soil described in Trial 1, over a layer of $5 \mathrm{~cm}$ of sand to allow adequate drainage. The soil was settled by the application of successive loads of water (until it equilibrated to a bulk density of approximately $1.4 \mathrm{Mg} \mathrm{m}^{-3}$ ) and salinized with potassium chloride ( $\mathrm{KCl}$ ) in solution with an 
EC of $12.5 \mathrm{dS} \mathrm{m}^{-1}$. It was irrigated with a volume of $1.6 \mathrm{~m}^{3}$ of solution, totaling five times the pore volume of the soil, until obtaining an EC of the soil solution similar to the one applied, which was obtained through suction lysimeters (SSAT, Irrometer, Riverside, USA). The experimental design was completely randomized, with two treatments (FA application and control), with three replicates each, totaling six containers. The dose of treatment (Ta) corresponded to the most effective in the leaching of salts according to the results obtained in Trial 1, while the other treatment (Tb) corresponds to the control without any kind of amendment.

\section{MATERIAL AND METHODS}

Trial 1: Previously calibrated FDR sensors (soil water content and bulk electric conductivity, GS3) were placed in the center of each column, which made it possible to obtain bulk EC $\left(\mathrm{EC}_{\mathrm{b}}\right)$ and water content in the first $5 \mathrm{~cm}$; all information was recorded in a datalogger (EM50, Decagon Devices, WA, USA).

The dose of FA from treatments T1, T2 and T3 was applied partially, 50\% in the first irrigation and $50 \%$ in the second, and then four irrigations were carried out. Each irrigation was applied for 17 minutes with a dripper of $4 \mathrm{~L} \mathrm{~h}^{-1}$ located at the center of the column, enough time to completely moisten the column. The volume of water applied for each irrigation was $1.15 \mathrm{~L}$ (approximately half the total porosity of the soil in the column). Once watered, it was allowed to drain freely for $48 \mathrm{~h}$ before the next irrigation. Additionally, the EC of the water used prior to irrigation was monitored, remaining stable at $1.04 \mathrm{dS} \mathrm{m}^{-1}$. To test the effect of the treatments, the $\mathrm{EC}_{\mathrm{b}}$ and soil water content were determined $48 \mathrm{~h}$ after each irrigation. Once the whole test was finished, a soil sample was taken from each column (0-10 cm depth) and soil extractable cations (extraction by ammonium acetate), CEC (extraction by ammonium acetate), $\mathrm{pH}$ (suspension and potentiometric determination) and SOM (calcination) were evaluated following the methodologies proposed by Sadzawka et al. (2006).

Trial 2: To extract the soil solution from the container, at the moment of applying the soil filling, five suction lysimeters (SSAT, Irrometer, Riverside, USA) were installed, $12 \mathrm{~cm}$ apart in depth and $15 \mathrm{~cm}$ apart laterally as it is shown in figure 1, establishing a grid that made it possible to monitor the movement of the salts in the profile according to the symmetry of the wet bulb in homogeneous porous media (8).

The letters A to $\mathrm{E}$ indicate the position of the five installed lysimeters.

Letras A a la E indican la posición de los 5 lisímetros instalados.
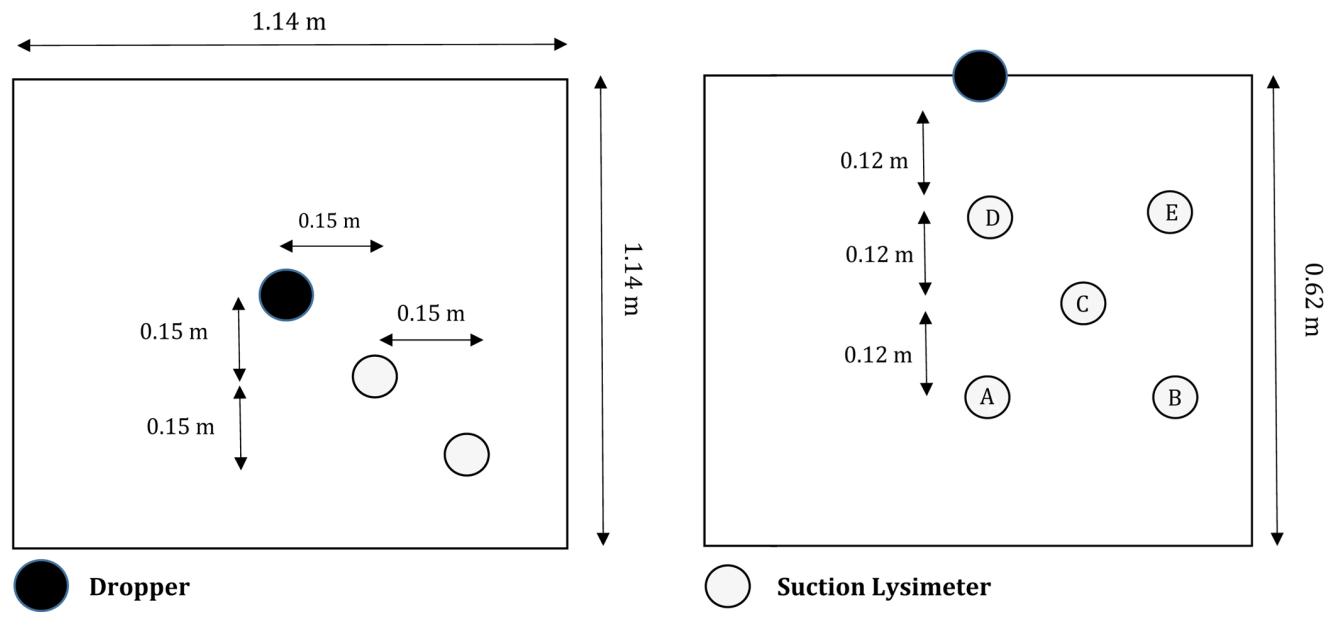

Figure 1. Suction lysimeters grid. On the left, flat view (width: $1.14 \mathrm{~m}$; length: $1.14 \mathrm{~m}$ ) ; right, longitudinal view (height: $0.62 \mathrm{~m}$ ).

Figura 1. Disposición de los lisímetros de succión. A la izquierda, vista plana; a la derecha, sección longitudinal. 
Once the assembly was made and the soil salinized at an approximate EC of the soil solution of $12.5 \mathrm{dS} \mathrm{m}{ }^{-1}, 6$ irrigations $48 \mathrm{~h}$ apart were applied using a dripper of $4 \mathrm{Lh}^{-1}$ located at the center of the container. The first irrigation was used for the application of FA (5.3 kg ha-1, most effective dose selected from Trial 1), while the remaining 5 were salt leaching irrigations. The volume of water applied in each irrigation was approximately $25 \%$ of the total soil porosity (82 L). After each irrigation, the soil was allowed to drain freely for $48 \mathrm{~h}$ to reach the field capacity; simultaneously, to avoid the contribution of water by precipitation and its loss from the soil by evaporation, the surface of the container was covered with a plastic cover. After $48 \mathrm{~h}$, the soil solution was extracted with the aforementioned lysimeters with a vacuum application between -70 and $-80 \mathrm{cb}$ for $1 \mathrm{~h}$. The EC of the extracted solution was determined with a CON510 conductivity meter (Oakton, Illinois, USA). As a control, the water EC was monitored prior to irrigation, fluctuating between 0.87 and $1.33 \mathrm{dS} \mathrm{m}^{-1}$. Based on the EC spatial data obtained from the 3 replicates, their average was interpolated using kriging, assuming a mirror image distribution and a soil profile of $0.4 \mathrm{~m}$ (depth) and $1 \mathrm{~m}$ (width). To visualize the displacement of salt (salinity contour lines) in the container after each irrigation, the software Surfer 13 was used. In addition, to numerically visualize the impact of each irrigation period in the displacement of salt, an analysis of the surface was carried out, taking as a reference the soil profile and its salinity contour lines obtained through the interpolation. This analysis shows the fraction of the area of the soil profile, expressed as a percentage of the total area, which is within a range of EC, obtained as a result of an irrigation.

\section{Statistical analysis}

The results of the measurements of the Trials 1 and 2 were analyzed statistically through an analysis of variance (ANOVA) with a confidence level of $95 \%$. To establish differences, the Tukey test was used with a $5 \%$ significance, comparing the means among treatments for an irrigation period (Trial 1) for salinity, the means among treatments for all the irrigation periods (Trial 1) for soil water content, and the means between treatments for a lysimeter's position and a determined irrigation period (Trial 2).

\section{Results}

Trial 1: Average soil water content was $0.36 \pm 0.013 \mathrm{~m}^{3} \mathrm{~m}^{-3}$ did not show differences among treatments and irrigation period $(\mathrm{P}>0.05)$. Under this condition, the differences in $\mathrm{EC}_{\mathrm{b}}$ between treatments are mainly due to the variation in the ion concentration of the soil solution. Table 1 (page 169), shows the evolution of $\mathrm{EC}_{\mathrm{b}}$ values by treatment measured 48 hours after irrigation. Statistical significant differences were found from the third irrigation, where the lowest values of $\mathrm{EC}_{\mathrm{b}}$ were obtained in $\mathrm{T} 2$ and $\mathrm{T} 3$, with no statistical differences between them, however T3 did not show differences with T0 and T1 while T2 did, showing in average a better performance. From irrigation 4 to 6 , the statistical differences between treatments were maintained, but T1 differed from T3, showing it to be the least effective treatment. On the other hand, T3 exhibited the same behavior as T0, which in turn showed no difference with T1. T2 (5.3 kg ha-1, FA dose) showed until the end to be statistically the most effective.

No significant pH differences were found in the soil columns at the end of the trial, standing around pH 9.0 (table 2, page 169). No differences were found in the SOM content or CEC as well (table 2, page 169). These results show that doses lower than $10.5 \mathrm{~kg} \mathrm{ha}^{-1}$ of FA applied under the conditions and soil used in this test did not affect the buffer capacity of the soil.

The distribution of extractable cations in the soil at the end of the trial is given in table 3 (page 169), which shows that there are no statistical differences between treatments. 
Note: T1, T2 and T3 correspond to doses of 2.1, 5.3 and $10.5 \mathrm{~kg} \mathrm{ha}^{-1}$

${ }^{\text {a }}$ Different letters indicate statistically significant differences between treatments in the same irrigation according to the Tukey test with a $5 \%$ significance.

Nota: T1, T2 y T3 corresponden a dosis de $2.1,5.3$ y $10.5 \mathrm{~kg} \mathrm{ha}^{-1}$

${ }^{\mathrm{a}}$ Las diferentes letras indican diferencias estadísticamente significativas entre los tratamientos en el mismo riego de acuerdo con la prueba de Tukey con una significancia del 5\%.

Note: T1, T2 and T3 correspond to fulvic acid doses of 2.1, 5.3 and $10.5 \mathrm{~kg} \mathrm{ha}^{-1}$.

a Different letters indicate statistically significant differences according to the Tukey test ( $5 \%$ significance).

Nota: T1, T2 y T3 corresponden a dosis de ácido fúlvico de 2.1, 5.3 y $10.5 \mathrm{~kg} \mathrm{ha}^{-1}$.

a Letras diferentes indican significancia estadística de acuerdo con el test de Tukey (5\% de significancia).

Note: T1, T2 and T3 correspond to fulvic acid doses of 2.1, 5.3 and $10.5 \mathrm{~kg} \mathrm{ha}^{-1}$

a Different letters indicate statistically significant differences between treatments according to the Tukey test ( $5 \%$ significance).

a Letras diferentes indican significancia estadística entre tratamientos de acuerdo con el test de Tukey ( $5 \%$ de significancia).
Table 1. Bulk Electrical Conductivity ( $\mathrm{EC}_{\mathrm{b}}$ 's values after 48 hours of irrigation). Average value and its standard deviation per treatment are presented.

Tabla 1. Conductividad eléctrica aparente (valores de $\mathrm{EC}_{\mathrm{b}}$ después de 48 horas de un riego). El valor promedio y su desviación standard son presentados.

\begin{tabular}{|c|c|c|c|}
\hline \multicolumn{4}{|c|}{$\mathrm{EC}_{\mathrm{b}}\left(\mathrm{dS} \mathrm{\textrm {m } ^ { - 1 } )}\right.$} \\
\hline Treatments & Irrigation 1 & Irrigation 2 & Irrigation 3 \\
\hline T0 & $0.945 \pm 0.086 \mathrm{a}^{\mathrm{a}}$ & $0.589 \pm 0.060 \mathrm{a}$ & $0.517 \pm 0.040 \mathrm{~b}$ \\
\hline $\mathrm{T} 1$ & $0.945 \pm 0.005 \mathrm{a}$ & $0.599 \pm 0.003 a$ & $0.538 \pm 0.005 \mathrm{~b}$ \\
\hline $\mathrm{T} 2$ & $0.945 \pm 0.120 \mathrm{a}$ & $0.515 \pm 0.088 \mathrm{a}$ & $0.406 \pm 0.051 \mathrm{a}$ \\
\hline T3 & $0.945 \pm 0.126 \mathrm{a}$ & $0.533 \pm 0.043 \mathrm{a}$ & $0.460 \pm 0.019 \mathrm{ab}$ \\
\hline Treatments & Irrigation 4 & Irrigation 5 & Irrigation 6 \\
\hline T0 & $0.493 \pm 0.038 \mathrm{bc}$ & $0.474 \pm 0.042 \mathrm{bc}$ & $0.464 \pm 0.042 \mathrm{bc}$ \\
\hline $\mathrm{T} 1$ & $0.513 \pm 0.009 \mathrm{c}$ & $0.497 \pm 0.007 \mathrm{c}$ & $0.484 \pm 0.007 \mathrm{c}$ \\
\hline $\mathrm{T} 2$ & $0.373 \pm 0.042 \mathrm{a}$ & $0.351 \pm 0.035 \mathrm{a}$ & $0.336 \pm 0.034 \mathrm{a}$ \\
\hline $\mathrm{T} 3$ & $0.428 \pm 0.008 \mathrm{ab}$ & $0.411 \pm 0.015 \mathrm{ab}$ & $0.399 \pm 0.017 \mathrm{ab}$ \\
\hline
\end{tabular}

Table 2. Average values of pH, organic matter, CEC and its standard deviation by treatments once the trial was finished.

Tabla 2. Valores promedio de $\mathrm{pH}$, materia orgánica, CEC y su desviación estándar para cada tratamiento una vez terminado el ensayo.

\begin{tabular}{|c|c|c|c|}
\hline \multirow{2}{*}{ Treatment } & pH & Organic Matter & CEC \\
\cline { 2 - 4 } & --- & g kgol $^{-1}$ & $22.19 \pm 1.15 \mathrm{a}$ \\
\hline T0 & $8.96 \pm 0.08 \mathrm{a}^{\mathrm{a}}$ & $0.0103 \pm 0.0003 \mathrm{a}$ & $19.78 \pm 1.57 \mathrm{a}$ \\
\hline T1 & $9.12 \pm 0.01 \mathrm{a}$ & $0.0107 \pm 0.0011 \mathrm{a}$ & $19.37 \pm 0.20 \mathrm{a}$ \\
\hline T2 & $8.96 \pm 0.25 \mathrm{a}$ & $0.0101 \pm 0.0041 \mathrm{a}$ & $21.56 \pm 1.34 \mathrm{a}$ \\
\hline T3 & $8.92 \pm 0.11 \mathrm{a}$ & $0.0106 \pm 0.0010 \mathrm{a}$ & \\
\hline
\end{tabular}

Table 3. Average values of pH, organic matter and CEC by treatments once the trial was finished.

Tabla 3. Valores promedio de pH, material orgánica y CEC para cada tratamiento una vez terminado el ensayo.

\begin{tabular}{|c|c|c|c|c|}
\hline \multirow{2}{*}{ Treatment } & $\mathbf{C a}^{2+}$ & $\mathbf{K}^{+}$ & $\mathbf{M g}^{2+}$ & $\mathbf{N a}^{+}$ \\
\cline { 2 - 5 } & \multicolumn{4}{|c|}{$--------\mathrm{cmol} \mathrm{kg}^{-1}-----------$} \\
\hline T0 & $16.70 \pm 5.09 \mathrm{a}^{\mathrm{a}}$ & $0.52 \pm 0.04 \mathrm{a}$ & $0.25 \pm 0.12 \mathrm{a}$ & $0.39 \pm 0.02 \mathrm{a}$ \\
\hline T1 & $17.75 \pm 7.71 \mathrm{a}$ & $0.55 \pm 0.01 \mathrm{a}$ & $0.22 \pm 0.10 \mathrm{a}$ & $0.40 \pm 0.01 \mathrm{a}$ \\
\hline T2 & $14.90 \pm 4.24 \mathrm{a}$ & $0.41 \pm 0.02 \mathrm{a}$ & $0.23 \pm 0.05 \mathrm{a}$ & $0.34 \pm 0.01 \mathrm{a}$ \\
\hline T3 & $16.15 \pm 0.64 \mathrm{a}$ & $0.53 \pm 0.05 \mathrm{a}$ & $0.16 \pm 0.06 \mathrm{a}$ & $0.38 \pm 0.06 \mathrm{a}$ \\
\hline
\end{tabular}


Trial 2: The most effective treatment $\left(\mathrm{T} 2=5.3 \mathrm{~kg} \mathrm{ha}^{-1}\right)$ from Trial 1 was selected to perform Ta in Trial 2. Table 4 shows the average soil solution EC and its standard deviation extracted by the lysimeters in each irrigation period. Statistical differences between treatments were observed $(\mathrm{p}<0.05)$ from the first irrigation (lysimeter B and E), position according figure 1 (page 167). These differences $(\mathrm{p}<0.05)$ were more consistent from the third irrigation involving a higher proportion of the soil profile (lysimeters A, B, C, E). The differences were maintained until the fifth irrigation, where $\mathrm{Tb}$ (Control) begins to equate the effects of Ta (5.3 $\left.\mathrm{kg} \mathrm{ha}^{-1} \mathrm{of} \mathrm{FA}\right)$ in the position of the C lysimeter, however differences were reached even in the sixth irrigation in the $\mathrm{B}$ and $\mathrm{E}$ lysimeters' positions. Therefore, it was observed from the first irrigation and until the end of the test, substantively lower EC values in the containers treated with FA (Ta), reaching differences of up to $8.6 \mathrm{dS} \mathrm{m}^{-1}$ (lysimeter E, Irrigation 2, table 4).

Table 4. Average EC values and its standard deviation of the solutions obtained with the lysimeters for each irrigation period (Ri), for Tb (Control) and Ta (5.3 $\mathrm{kg} \mathrm{ha}^{-1}$ of fulvic acid).

Tabla 4. Valores promedio de la EC y su desviación estándar de las soluciones obtenidos con los lisímetros para cada periodo de riego (Ri), para Tb (Control) y Ta (5.3 $\mathrm{kg} \mathrm{ha}^{-1}$ de ácido fúlvico).

\begin{tabular}{|c|c|c|c|c|c|c|}
\hline & \multicolumn{2}{|c|}{ R1 } & \multicolumn{2}{|c|}{ R2 } & \multicolumn{2}{|c|}{ R3 } \\
\hline & $\mathbf{T b}$ & Ta & $\mathbf{T b}$ & Ta & $\mathbf{T b}$ & Ta \\
\hline & $\begin{array}{c}\mathrm{EC} \\
\mathrm{dSm}^{-1} \\
\end{array}$ & $\begin{array}{c}\mathrm{EC} \\
\mathrm{dSm}^{-1}\end{array}$ & $\begin{array}{c}\mathrm{EC} \\
\mathrm{dSm}^{-1}\end{array}$ & $\begin{array}{c}\mathrm{EC} \\
\mathrm{dSm}^{-1}\end{array}$ & $\begin{array}{c}\mathrm{EC} \\
\mathrm{dSm}^{-1}\end{array}$ & $\begin{array}{c}\mathrm{EC} \\
\mathrm{dSm}^{-1}\end{array}$ \\
\hline A & $11.83 \pm 1.50 \mathrm{a}$ & $11.85 \pm 0.54 \mathrm{a}$ & $10.97 \pm 1.81 \mathrm{a}$ & $9.44 \pm 1.15 \mathrm{a}$ & $8.37 \pm 2.35 \mathrm{~b}$ & $5.37 \pm 0.68 \mathrm{a}$ \\
\hline $\mathrm{B}$ & $12.53 \pm 0.38 \mathrm{~b}$ & $11.64 \pm 0.36 \mathrm{a}$ & $12.96 \pm 0.02 \mathrm{~b}$ & $7.29 \pm 0.96 \mathrm{a}$ & $10.51 \pm 2.62 \mathrm{~b}$ & $2.68 \pm 0.44 \mathrm{a}$ \\
\hline $\mathrm{C}$ & $11.37 \pm 2.12 \mathrm{a}$ & $12.36 \pm 0.16 \mathrm{a}$ & $11.84 \pm 1.45 \mathrm{~b}$ & $9.72 \pm 0.66 \mathrm{a}$ & $8.07 \pm 3.62 b$ & $4.30 \pm 0.81 \mathrm{a}$ \\
\hline $\mathrm{D}$ & $4.72 \pm 1.58 \mathrm{a}$ & $4.94 \pm 1.41 \mathrm{a}$ & $2.82 \pm 0.41 \mathrm{a}$ & $2.20 \pm 0.53 \mathrm{a}$ & $1.55 \pm 0.30 \mathrm{a}$ & $1.66 \pm 0.10 \mathrm{a}$ \\
\hline \multirow[t]{4}{*}{$\mathrm{E}$} & $13.47 \pm 0.66 \mathrm{~b}$ & $9.38 \pm 1.94 \mathrm{a}$ & $12.65 \pm 1.06 \mathrm{~b}$ & $3.97 \pm 0.64 \mathrm{a}$ & $8.48 \pm 4.51 b$ & $1.50 \pm 0.36 a$ \\
\hline & \multicolumn{2}{|c|}{ R4 } & \multicolumn{2}{|c|}{ R5 } & \multicolumn{2}{|c|}{ R6 } \\
\hline & $\mathbf{T b}$ & Ta & Tb & Ta & Tb & Ta \\
\hline & $\begin{array}{c}\text { EC } \\
\mathrm{dSm}^{-1}\end{array}$ & $\begin{array}{c}\mathrm{EC} \\
\mathrm{dSm}^{-1}\end{array}$ & $\begin{array}{c}\mathrm{EC} \\
\mathrm{dSm}{ }^{-1}\end{array}$ & $\begin{array}{c}\mathrm{EC} \\
\mathrm{dSm}^{-1}\end{array}$ & $\begin{array}{c}E C \\
\mathrm{dSm}^{-1}\end{array}$ & $\begin{array}{c}\mathrm{EC} \\
\mathrm{dSm}^{-1}\end{array}$ \\
\hline A & $5.10 \pm 1.66 \mathrm{~b}$ & $2.77 \pm 0.15 \mathrm{a}$ & $4.00 \pm 1.15 b$ & $2.17 \pm 0.34 \mathrm{a}$ & $3.89 \pm 1.63 \mathrm{a}$ & $2.07 \pm 0.77 \mathrm{a}$ \\
\hline $\mathrm{B}$ & $8.81 \pm 4.82 \mathrm{~b}$ & $1.98 \pm 0.01 \mathrm{a}$ & $6.31 \pm 3.16 \mathrm{~b}$ & $1.65 \pm 0.03 \mathrm{a}$ & $4.18 \pm 0.81 \mathrm{~b}$ & $1.92 \pm 0.40 \mathrm{a}$ \\
\hline $\mathrm{C}$ & $6.17 \pm 2.84 \mathrm{~b}$ & $3.17 \pm 1.04 \mathrm{a}$ & $4.62 \pm 2.07 \mathrm{a}$ & $2.51 \pm 0.85 \mathrm{a}$ & $3.41 \pm 1.57 \mathrm{a}$ & $2.72 \pm 0.41 \mathrm{a}$ \\
\hline $\mathrm{D}$ & $1.49 \pm 0.15 \mathrm{a}$ & $1.56 \pm 0.11 \mathrm{a}$ & $1.32 \pm 0.22 \mathrm{a}$ & $1.44 \pm 0.08 \mathrm{a}$ & $1.44 \pm 0.31 \mathrm{a}$ & $1.63 \pm 0.20 \mathrm{a}$ \\
\hline$E$ & $7.15 \pm 5.30 \mathrm{~b}$ & $1.60 \pm 0.07 \mathrm{a}$ & $5.17 \pm 2.37 \mathrm{~b}$ & $1.34 \pm 0.27 \mathrm{a}$ & $3.55 \pm 1.57 \mathrm{~b}$ & $1.54 \pm 0.30 \mathrm{a}$ \\
\hline
\end{tabular}

Note: R1 to R6= irrigation period, A to $\mathrm{E}=$ lysimeters' position (figure 1, page 167).

${ }^{a}$ Different letters indicate statistically significant differences according to the Tukey test ( $5 \%$ significance), between treatments for each irrigation period and each lysimeter position.

Nota: R1 a R6= periodo de riego, A to E = posición de lisímetros (figura 1, page 167).

${ }^{a}$ Letras diferentes indican significancia estadística de acuerdo con el test de Tukey (5\% de significancia), entre tratamientos para cada periodo de riego y cada posición de lisímetro.

Figure 2 (page 171), shows the evolution of the salinity of the soil solution as a function of the irrigations, the figure is consistent with the results from table 4, and also depicted the greater opening of the salinity bulb generated with the FA treatment. By comparing the dispersion of EC values in-depth between treatments, the impact of the use of FA is accentuated if a more efficient use of water available for irrigation is considered. For example, it is observed that the dispersion of the EC obtained at the sixth irrigation in the $\mathrm{Tb}$ (control) is similar to that achieved in the third irrigation with the application of the FA (figure 2, page 171). A similar conclusion could be inferred from table 1 (page 169), (Trial 1) where after the third irrigation with $5.3 \mathrm{~kg} \mathrm{ha}^{-1}$ dose, soil $\mathrm{EC}_{\mathrm{b}}$ is $0.406 \mathrm{dS} \mathrm{m}^{-1}$, which is below the level of $0.464 \mathrm{dS} \mathrm{m}^{-1}$ obtained in the Control with six irrigations. 


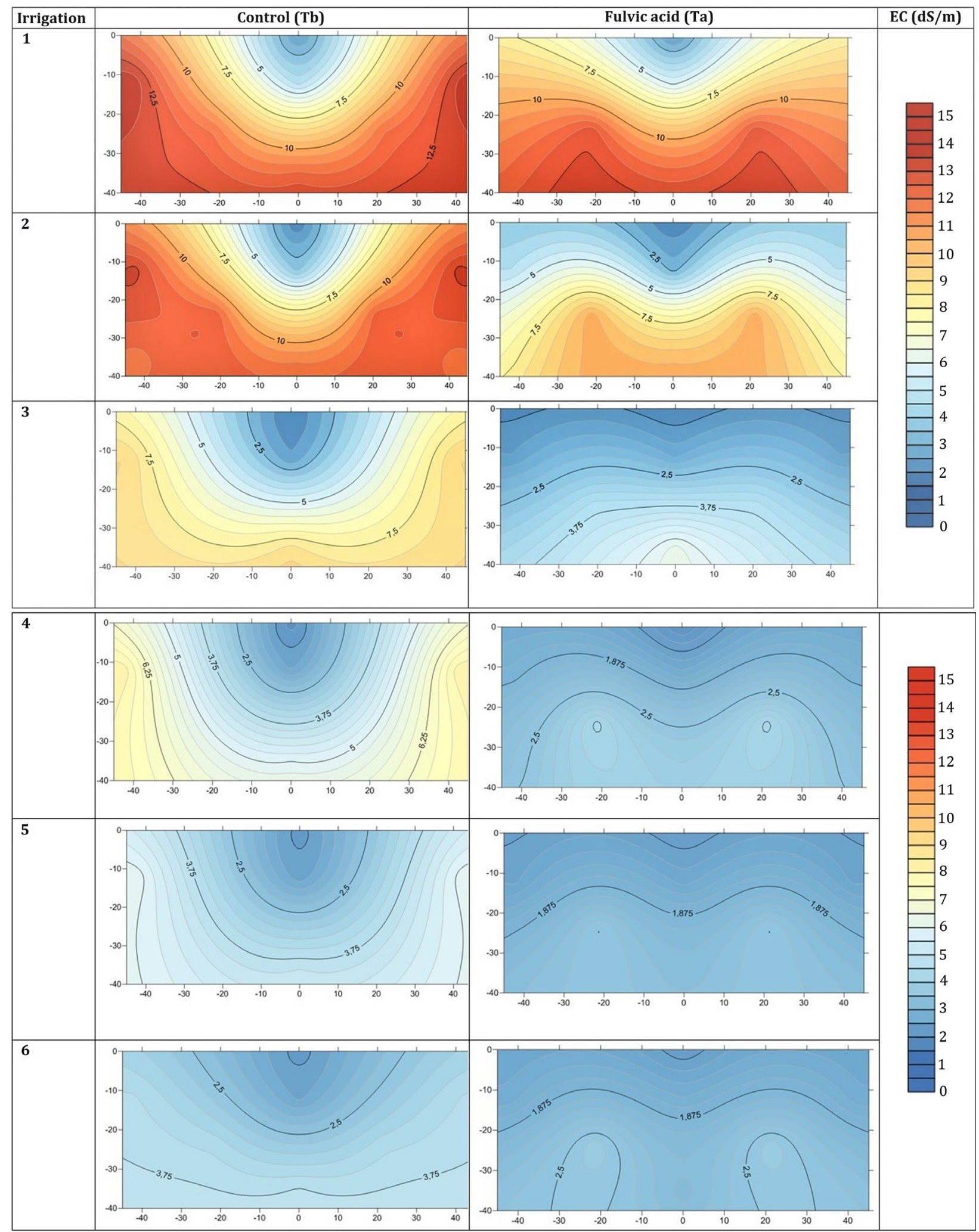

Figure 2. Isosalinity contour lines. As a result of the interpolation from the average EC values of the soil solutions obtained with the lysimeters for each irrigation period. Tb (Control) and Ta (5.3 $\mathrm{kg} \mathrm{ha}^{-1}$ of fulvic acid).

Figura 2. Curvas de isosalinidad. Como resultado de la interpolación de los valores de CE promedio de las soluciones de suelo obtenidas con los lisímetros para cada período de riego. Tb (Control) y Ta (5,3 $\mathrm{kg} \mathrm{ha}^{-1}$ de ácido fúlvico). 
Therefore, based on the observation from figure 2 (page 171) and under the conditions of this test, it may be inferred that a decrease in EC from 12.5 to $3.75 \mathrm{dS} \mathrm{m}^{-1}$ at $30 \mathrm{~cm}$ depth for a surface of $1.3 \mathrm{~m}^{2}$ is achieved either by applying $449.8 \mathrm{~L}$ of irrigation water $\left(\mathrm{EC}=1.04 \mathrm{dS} \mathrm{m}^{-1}\right)$ or by irrigating with $203.5 \mathrm{~L}$ of the same water plus an application of $5.3 \mathrm{~kg} \mathrm{ha}^{-1}$ of FA, generating a water consumption equivalent to $45.2 \%$ of the control. This result supposes that an application of $5.3 \mathrm{~kg} \mathrm{ha}^{-1}$ of FA would be equivalent to $246.3 \mathrm{~L}$ of water in the washing of salts for that surface.

Table 5 presents the fraction of the area of the soil profile expressed as a percentage of the total area for a range of EC obtained as a result of irrigation. The results are consistent with table 4 (page 170); figure 2 (page 171) , and it is observed that from the first irrigation the fraction of the area with lower EC ranges increased more rapidly using FA. For example, it is inferred that in irrigation 3, for the treatment with FA (Ta), 97.9\% of the profile's cross section has EC values lower than $5 \mathrm{dSm}^{-1}$ while $\mathrm{Tb}$ (control) only 25, 8\%.

Table 5. Fraction of the area of the soil profile expressed as a percentage of the total area for an EC (average) range obtained as a result of an irrigation period. Tb (Control) and Ta (5.3 $\mathrm{kg} \mathrm{ha}^{-1}$ of fulvic acid).

Tabla 5. Fracción del área del perfil del suelo expresada como porcentaje del área total para un rango de EC (promedio) obtenido como resultado de un período de riego. $\mathrm{Tb}$ (Control) y Ta (5,3 $\mathrm{kg} \mathrm{ha}^{-1}$ de ácido fúlvico).

Note: Tb (Control) and Ta (5.3 $\mathrm{kg} \mathrm{ha}^{-1}$ of fulvic acid); $\mathrm{R}$ corresponds to the irrigation period. Nota: $\mathrm{Tb}$ (Control) y Ta $\left(5,3 \mathrm{~kg} \mathrm{ha}^{-1}\right.$ de ácido fúlvico); R corresponde al periodo de riego.

\begin{tabular}{|l|r|r|r|r|r|r|r|r|r|r|c|c|}
\hline \multicolumn{1}{|c|}{ CE } & \multicolumn{9}{|c|}{ Tb } & \multicolumn{6}{c|}{ Ta } \\
\hline $\left.\mathbf{( d S m}^{-1}\right)$ & R1 & R2 & R3 & R4 & R5 & R6 & R1 & R2 & R3 & R4 & R5 & R6 \\
\hline $0-2.5$ & 1.0 & 2.1 & 7.1 & 10.3 & 16.2 & 21.7 & 0.7 & 5.2 & 44.8 & 58.2 & 100 & 86.5 \\
\hline $2.5-5$ & 6.9 & 7.5 & 18.7 & 37.4 & 77.9 & 78.3 & 6.2 & 28.5 & 53.1 & 41.8 & - & 13.5 \\
\hline $5-7.5$ & 12.9 & 10.9 & 40.6 & 52.4 & 5.9 & - & 13.9 & 28.0 & 2.2 & - & - & - \\
\hline $7.5-10$ & 16.1 & 18.2 & 33.6 & - & - & - & 27.3 & 38.2 & - & - & - & - \\
\hline $10-12.5$ & 63.0 & 61.2 & - & - & - & - & 52.0 & - & - & - & - & - \\
\hline Total & 100 & 100 & 100 & 100 & 100 & 100 & 100 & 100 & 100 & 100 & 100 & 100 \\
\hline
\end{tabular}

\section{Discussion}

In trial 1 , the $\mathrm{T} 1$ dose $\left(2.1 \mathrm{~kg} \mathrm{ha}^{-1}\right)$ was not enough to show positive effects on the soil, whereas the T3 dose $\left(10.5 \mathrm{~kg} \mathrm{ha}^{-1}\right)$, being much higher, was able to cause the FA to complex with each other, being dragged in masse, with little participation of other cations. Norambuena et al. (2014), working with a sandy loam soil with no salinity problems, demonstrated that increasing doses of humic+ gypsum substances generate an initial increase in water infiltration, with a subsequent decrease depending on the interaction of the organic amendment with the gypsum; the explanation may be a dispersion effect generated by high doses, considering the high reactivity of these substances, which generates a chemical seal that hinders the movement of water.

The fastest decrease of EC by the action of fulvic acid in the T2 treatment could be explained by its capacity to generate organo-mineral soluble complexes, where the selectivity of the cation to be transported is given by its ionic radius and the electrochemical affinity of the ligands $(4,6,23)$. The most obvious cause of this phenomenon corresponds to the neutralization of charges (23). The metal-organic matter complexes, once formed, follow three routes: (1) they are sorbed at exchange sites, (2) they coprecipitate, (3) the metal competes with other metals in the complex, some of which are able to precipitate as hydroxides and carbonates; these last two cases are hardly reversible (23). Ettler et al. (2009) found such organo-mineral complexes in soil leachates after the application of organic acids, which suggests that organic acids of low molecular weight (citric, acetic, malic acids, etc.) and those of high molecular weight (fulvic and humic acids) could increase the mobility of metal cations in the soil. 
This phenomenon is favored at lower $\mathrm{pH}$ values due to the variable charge present in organic molecules $(3,6)$. In our study, irrigation water had no influence on the $\mathrm{pH}$ increase (table 2, page 169), and this may be responding to the result of the SOM stabilization process during its microbiological decomposition, as noted by Rowley et al. (2018) for the first stages of decomposition, where SOM occlusion process is generated at macroscale level (aggregates 250-2000 $\mu \mathrm{m}$ ). As a complement, Mahmoodabadi et al. (2013) state that the movement of cations will be given by the initial condition of the soil (concentration and type of cations present) and the type of SOM. In the present assay, no differences were observed between the extractable cations (table 3, page 169), being $\mathrm{Ca}^{+2}$ the dominant in the exchange complex, despite soil was treated with $\mathrm{KCl}$. Rowley et al. (2018) highlight the dominance of $\mathrm{Ca}^{+2}$ in the exchange complex, with an apparent occlusion capacity of organic matter. In this sense, soil presented $0.011 \mathrm{~g} \mathrm{~kg}^{-1}$ of SOM, with no differences between treatments at the end of the trial; thus, SOM content could interfere in the EC results.

The treatments with respect to the control did not generate an effect of decreasing the concentration of a particular cation (table 3, page 169), which can be explained by the high retention force of these elements attributable to a high $\mathrm{pH}$ of the soil where $\mathrm{OH}$ - anions predominate. The absence of statistically significant differences between treatments indicates that there was no tendency for FA to displace any particular cation, so they all moved according to their participation in the exchange complex.

Figure 2 (page 171) shows the effect of the application of FA (concentration of $5.3 \mathrm{~kg} \mathrm{ha}^{-1}$ ) on the composition of salinity bulbs (Trial 2), which are much more horizontally extended, with less curved isolines of less curvature with respect to the dripper (located in 0,0 coordinate) when compared to the control without application. Moreover, from the third irrigation, relatively flat isolines are generated, an effect enhanced by the surfactant characteristics of this organic acid, allowing for a better soil wetting (11).

On the other hand, the Ta (5.3 $\mathrm{kg} \mathrm{ha}^{-1}$ of FA) modified the distribution of the solutes in such a way that when comparing the salinity bulbs (figure 2, page 171), it is observed that the contour lines for the same EC value circumscribe a larger area in the containers treated with organic acids. This is evident in table 5 (page 172), where the percentage of the profile area is shown by EC sections in each irrigation as a percentage of the total area of the profile. The action of the organic acid is not determined exclusively by chemical aspects, but also by an improvement in the physical properties of the soil, mainly a greater stability and porosity (16), which determine a greater water flow capacity (17), optimizing the leaching of salts. However, as pointed out by Wuddivira and Camps-Roach (2007), the final effect depends on the content and type of clay, having dispersion processes in 2:1 minerals in high doses of organic amendments. This is how the Ta already has a profile with an EC of $5 \mathrm{dS} \mathrm{m}^{-1}$ or less at the fourth irrigation, while the $\mathrm{Tb}$ only has an area under these conditions of $47.7 \%$. Following this same analysis Ta reaches the total soil profile under $2.5 \mathrm{dS} \mathrm{m}^{-1}$ at the fifth irrigation, while $\mathrm{Tb}$ at the sixth irrigation only reaches $21.7 \%$ of the area of the container below this threshold. Our results poses new challenges for future studies in which it is desired to use humic amendments for the recovery of soils degraded by salinization processes.

\section{Conclusions}

Application of FA (5.3 $\mathrm{kg} \mathrm{ha}^{-1}$ ) reduced the water use by $50 \%$ compared to leaching carried out exclusively with water. The effective dose selected for salt leaching was found to be more than twice the recommended dose $\left(2.1 \mathrm{~kg} \mathrm{ha}^{-1}\right)$ and it turned out this latter did not show differences with the control (only water). These results impose some additional cost challenges to use this product more widely in agriculture. These challenges must be contrasted with the cost of irrigation water use that is becoming scarce, especially in arid and semi-arid regions. Future research should be conducted in order to know the persistence of the soil properties imposed by the product, to obtain a broader perspective of its use for future users. In general, these preliminary results reflect the use of fulvic acid as an alternative to consider in the recovery of saline soils under drip irrigation when irrigation water is scarce. 


\section{REFERENCES}

1. Beltrán Santoyo, M. Á.; Álvarez Fuentes, G.; Pinos Rodríguez, J. M.; García Lopez, J. C.; Castro Rivera, R. 2017. Abonos obtenidos del compostado de heces de ganado bovino de leche vs. fertilizante en la producción de triticale ( $X$ Triticum secale Wittmack). Revista de la Facultad de Ciencias Agrarias. Universidad Nacional de Cuyo. Mendoza. Argentina. 49(1): 95-104.

2. Ben-Hur, M.; Keren, R. 1997. Polymer effects on water infiltration and soil aggregation. Soil Sci Soc Am J 61: 565-570. https://doi: 10.2136/sssaj1997.03615995006100020028x

3. Casierra-Posada, F.; Rodríguez, C.; Fisher, G. 2009. Reducing negative effects of salinity in tomato (Solanum lycopersicum L.) plants by adding leonardite to soil. Acta Hortic. 821: 133-140. https:// doi:10.17660/ActaHortic.2009.821.14.

4. Chirenje, T.; Rivero, C.; Ma, L. 2002. Leachability of $\mathrm{Cu}$ and $\mathrm{Ni}$, in Wood ash-anmended soil as impacted by humic and fulvic acid. Geoderma. 108: 31-47. https://doi: 10.1016/S00167061(02)00120-9.

5. El-Shakweer, M. H. A.; El-Sayad, E. A.; Ewees, M. S. A. 1998. Soil and plant analysis as a guide for interpretation of the improvement efficiency of organic conditioners added to different soils in Egypt. Commun Soil Sci Plan. 29: 2067-2088. https://doi. org/10.1080/00103629809370094.

6. Ettler, V.; Jehlicka, J.; Masek, V.; Hruska, J. 2005. The leaching behavior of lead metallurgical slag in high-molecular-weight (HMW) organic solutions. Mineral. Mag. 69: 737-747. https://doi. org/10.1180/0026461056950284.

7. Ettler, V.; Vrtiskova, R.; Mihaljevic, M.; Sebek, O.; Grygar, T.; Drahota, P. 2009. Cadmium, lead and zinc leaching from smelter fly ash in simple organic acids - Simulators of rhizospheric soil solutions. J.Hazard. Mater 170: 1264-1268. https:// doi: 10.1016/j.jhazmat.2009.05.068.

8. Gil, M.; Rodríguez, L.; Benítez, J.; Sánchez, R.; Juana, L.; Castañon, G.; Laguna, F. 2011. Utilización del "dfot heat pulse method" para el estudio del bulbo mojado en goteros. In: "X Jornadas de Investigación de la Zona no Saturada del Suelo", 2011. Salamanca. España. 154-159.

9. Hamdy, A.; Sfeir, P. 2002. Use of soil conditioners under saline irrigation: effect on wheat. Acta Hortic. 573: 339-348. https://doi.org/10.17660/Acta Hortic.2002.573.39.

10. Hilhorst, M. 2000. A pore water conductivity sensor. Soil Sci Soc Am J. 64:1922-1925. https://doi: 10.2136/sssaj2000.6461922x.

11. Klavins, M.; Purmalis, O. 2010. Humic substances as surfactants. Environmental Chemistry Letters. 8: 349-354. https://doi.org/10.1007/s10311-009-0232-z.

12. Lakhdar, A.; Hafsi, C.; Rabhi, M.; Debez, A.; Montemurro, F; Abdelly, C.; Jedidi, N.; Ouerghi, Z. 2008. Application of municipal solid waste compost reduces the negative effects of saline water in Hordeum maritimum L. Bioresour Technol. 99: 7160-7167. https:// doi: 10.1016/j. biortech.2007.12.071.

13. Mahmoodabadi, M.; Yazdanpanah, N.; Rodríguez, L.; Pazira, E.; Neshat, A. 2013. Reclamation of calcareous saline sodic soil with different amendments (I): Redistribution of soluble cations within the soil profile. Agric. Water Manage. 120(1): 30-38. https://doi: 10.1016/j. agwat.2012.08.018.

14. Merwad, A. M. A.; Abdel-Fattah, M. K. 2015. Effect of some soil amendments and foliar spray of salicylic and ascorbic acids on sorghum under saline calcareous soil conditions. Int J Soil Sci. 10: 28-36. https://doi:10.3923/ijss.2015.28.36.

15. Merwad, A. M. A. 2017. Effect of humic and fulvic substances and Moringa leaf extract on Sudan grass plants grown under saline conditions. Can J Soil Sci. 97: 703-716. https://doi. org/10.1139/cjss-2017-0050.

16. Nan, J.; Chen, X.; Chen, C.; Siddique Lashari, M.; Deng, J.; Du, Z. 2016. Impact of flue gas desulfurization gypsum and lignite humic acid application on soil organic matter and physical properties of a saline-sodic farmland soil in Eastern China. J Soils Sediments. 16: 2175-2185. https:// doi:10.1007/s11368-016-1419-0.

17. Norambuena, M.; Neaman, A.; Schiappacasse, M. C.; Salgado, E. 2014. Effect of liquid humus and calcium sulphate on soil aggregation. J Soil Sci Plant Nut. 14: 701-709. https://doi:10.4067/ S0718-95162014005000056.

18. Osman A.; Ewees, M. 2008. The possible use of humic acid incorporated with drip irrigation system to alleviate the harmful effects of saline water on tomato plants. J Agric Res Dev. 22: 52-70.

19. Ouni, Y.; Ghnaya, T.; Montemurro, F.; Abdelly, Ch.; Lakhdar, A. 2014. The role of humic substances in mitigating the harmful effects of soil salinity and improve plant nutrition. Int J Plant Prod. 8: 353-374. https://doi: 10.22069/IJPP.2014.1614.

20. Rady, M. 2012. A novel organo-mineral fertilizer can mitigate salinity stress effects for tomato production on reclaimed saline soil. S African J Bot. 8: 8-14. http//doi.org/10.1016/j. sajb.2012.03.013.

21. Rowley, M. C.; Grand, S.; Verrecchia, E. P. 2018. Calcium-mediated stabilization of soil organic carbon. Biogeochemistry. 137: 27-49. https://doi.org/10.1007/s10533-017-0410-1.

22. Sadzawka, A.; Carrasco, M.; Grez, R.; Mora, M.; Flores, H.; Neaman, A. 2006. Métodos de análisis recomendados para los suelos de Chile, Instituto de Investigaciones Agropecuarias. Serie Actas INIA N ${ }^{\circ} 34$. Santiago. Chile. 
23. Singh, A.; Pandeya, B. 1998. Sorption and release of cadmium-fulvic acid complexes in sludge treated soils. Bioresour Technol. 66: 119-127. https://doi: 10.1016/S0960-8524(98)00035-2

24. Tejada, M.; García, C.; González, J.; Hernández, M. 2006. Use of organic amendment as a strategy for saline soil remediation: Influence on the physical, chemical and biological properties of soil. Soil Biol Biochem. 38(6): 1413-1421. https://doi.org/10.1016/j.soilbio.2005.10.017.

25. Wuddivira, M. N.; Camps-Roach, G. 2007. Effects of organic matter and calcium on soil structural stability. Eur J Soil Sci. 58: 722-727. https://doi.org/10.1111/j.1365-2389.2006.00861.x

26. Zhang, T.; Wang, T.; Liu, K.; Wang, L.; Wang, K.; Zhou, Y. 2015. Effects of different amendments for the reclamation of coastal saline soil on soil nutrient dynamics and electrical conductivity responses. Agric Water Manage. 159: 115-122. https://doi.org/10.1016/j. agwat.2015.06.002. 